\section{SANDIA REPORT}

SAND92-2377 - UC -722

Unlimited Release

Printed November 1992
RETANN HARDCOPY

\title{
Vibration and Shock Test Report for the H1616-1 Container and the Savannah River Hydride Transport Vessel
}

\author{
Allen R. York II, Brian J. Joseph
}

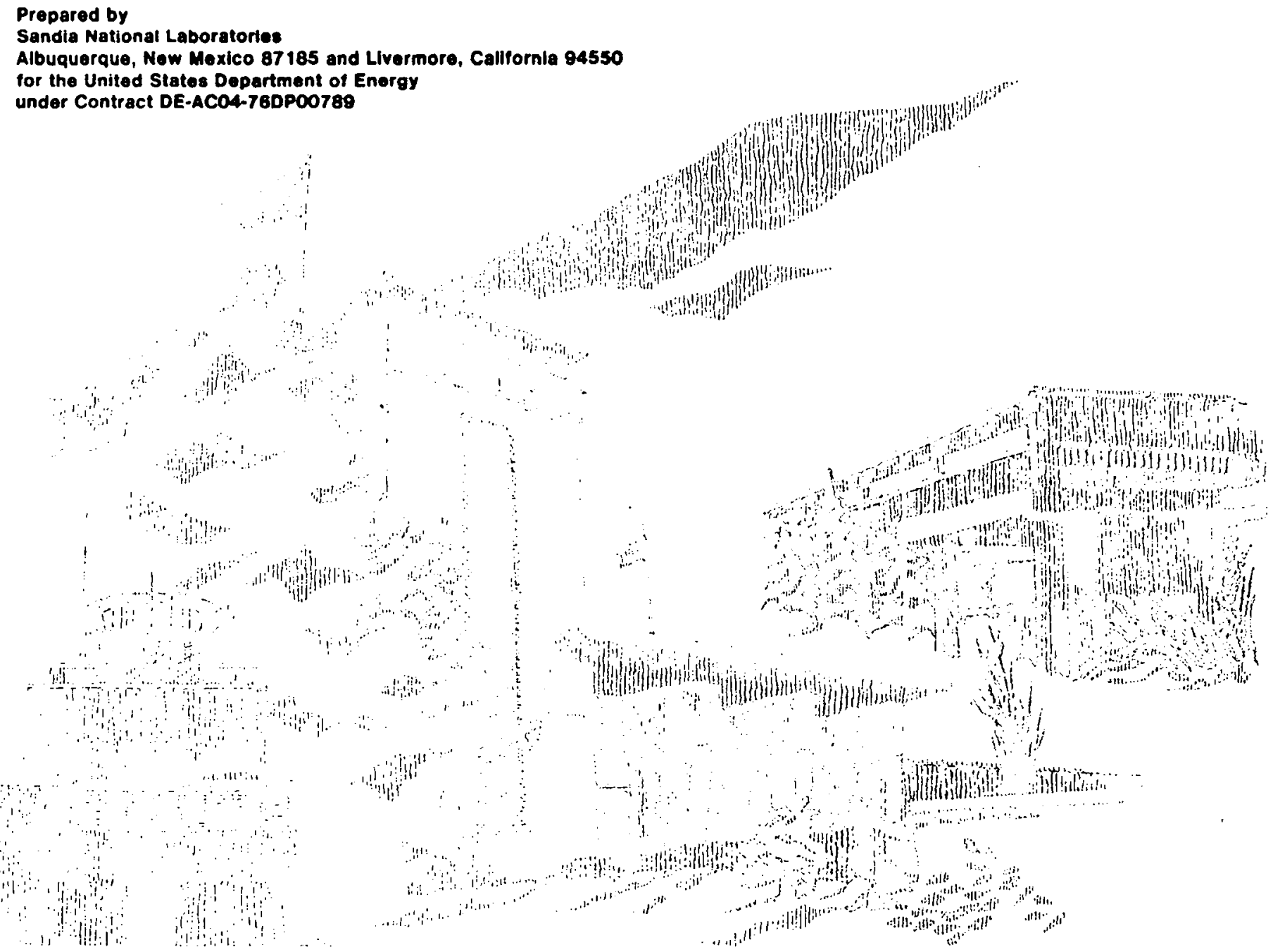


Issued by Sandia National Laboratories, operated for the United States Department of Energy by Sandia Corporation.

NOTIC2: This report was prepared as an account of work sponsored by an agency of the United States Government. Neither the United States Govern. ment nor any agency thereof, nor any of their employees, nor any of their contractors, subcontractors, or their employees, makes any warranty, express or implied, or assumes any legal liability or responsibility for the accuracy, completeness, or usefulness of any information, apparatus, product, or process disclosed, or represents that its use would not infringe privately owned rights. Reference herein to any specific commercial product, process, or service by trade name, trademark, manufacturer, or otherwise, does not necessarily constitute or imply its endorsement, recommendation, or favoring by the United States Government, any agency thereof or any of their contractors or subcontractors. The views and opinions expressed herein do not necessarily state or reflect those of the United States Government, any agency thereof or any of their contractors.

Printed in the United States of America. This report has been reproduced directly from the best available copy.

Available to DOE and DOE contractors from

Office of Scientific and Technical Information

PO Box 62

Oak Ridge, TN 37831

Prices available from (615) 576-8401, FTS 626-8401

Available to the public from

National Technical Information Service

US Department of Commerce

5285 Port Royal Rd

Springfield, VA 22161

NTIS price codes

Printed copy: A08

Microfiche copy: A01 
SAND92-2377

Distribution

Unlimited Release

Printed November 1992

Category UC-722

\title{
VIBRATION AND SHOCK TEST REPORT FOR THE H1616-1 \\ CONTAINER AND THE SAVANNAH RIVER \\ HYDRIDE TRANSPORT VESSEL
}

\author{
Allen R. York, II and Brian J. Joseph \\ Advanced Systems Department \\ Sandia National Laboratories \\ Albuquerque, NM 87185
}

\begin{abstract}
Sandia National Laboratories performed random vibration and shock tests on a tritium hydride transport vessel that was packaged in an H1616-1 container. The objective of the tests was to determine if the hydride transport vessel remains leaktight under vibration and shock normally incident to transport, which is a requirement that the hydride transport vessel must meet to be shipped in the H1616-1. Helium leak tests before and after the vibration and shock tests showed that the hydride transport vessel remained leaktight under the specified conditions. There were no detrimental effects on the containment vessel of the H1616-1.
\end{abstract}




\section{Table of Contents}

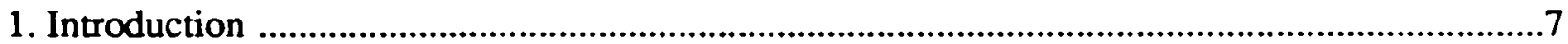

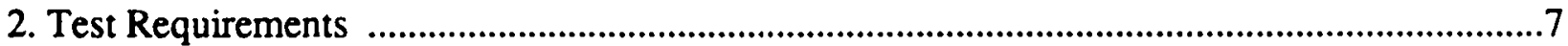

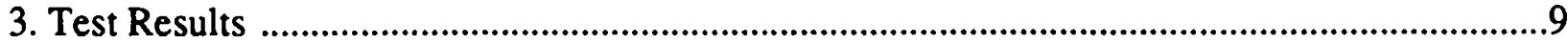

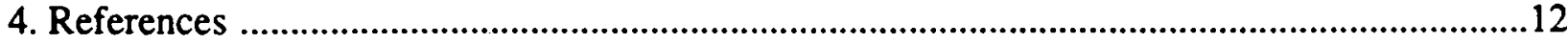

Appendix A - Purchase Requisition No. D88600 Including Statement of Work ........................13

Appendix B - Plan for Testing the H1616 and the Savannah River Hydride Transport Vessel ...20

Appendix C - Test Data Sheet and Test Notes ......................................................................28

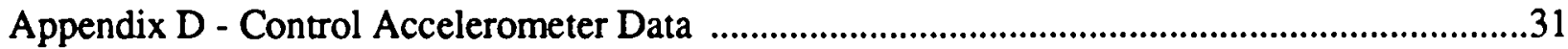

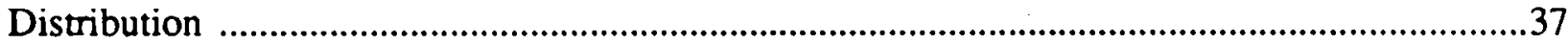

\section{List of Figures}

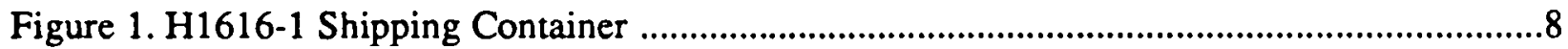

Figure 2. (a) HTV, (b) Initial Leak Testing of the HTV .....................................................10

Figure 3. (a) Pressurization of the HTV, (b) H1616-1 Mounted on the Vibration Table .............11 


\section{VIBRATION AND SHOCK TEST REPORT FOR THE H1616-1 \\ CONTAINER AND THE SAVANNAH RIVER \\ HYDRIDE TRANSPORT VESSEL}

\section{Introduction}

Sandia National Laboratories performed vibration and shock testing on an H1616-1 productiontype shipping container (Figure 1) loaded with a Hydride Transport Vessel (HTV) as the contents. This testing was performed according to the Work Scope which formed part of the Savannah River (SR) purchase requisition No. D88600 (Appendix A). This report documents the vibration and shock tests and results.

\section{Test Requirements}

The basic test requirement is that the HTV be exposed to vibration and shock normally incident to transport and subsequently be evaluated for leakage. To meet this requirement, a full-scale H1616-1 and a full-scale HTV were assembled together, and simulated transportation environments were input to the H1616-1. Thus, the HTV experienced environments transferred through the H1616-1 as will occur in an actual shipment. For use in the H1616-1, the HTV must remain leaktight to $<1 \times 10^{-7} \mathrm{std} \mathrm{cc} / \mathrm{s}$ helium during and following exposure to these normal environments.

Transportation environment test specifications such as road and air transport vibration and shock are listed in Transportation Environments of the AL-SX (H1616) [1]. These test specifications and test durations were compiled into a test plan that served as the test control document (Appendix $B$ ). The durations that were used for the tests represent the worst-case durations as determined by SR.

Testing was performed with the H1616-1 in a vertical orientation, which is the orientation used for shipment. Vibration test duration was that to which an HTV would be exposed for transport from the user to the final destination including all foreseeable air flights, takeoff/landings, and transfers. Since the HTV is free to migrate inside the containment vessel of the H1616, only the initial orientation was known. However, the HTV received excitation in many different orientations due to the migration, just as would occur in an actual shipment.

Prior to the tests, the HTV was pressurized to 212 psia with helium. The H1616-1/HTV assembly was subjected to a total of $30 \mathrm{hr} 10$ minutes of random vibration and 16 handling shocks as described in Section 5 of the test plan (Appendix B). 


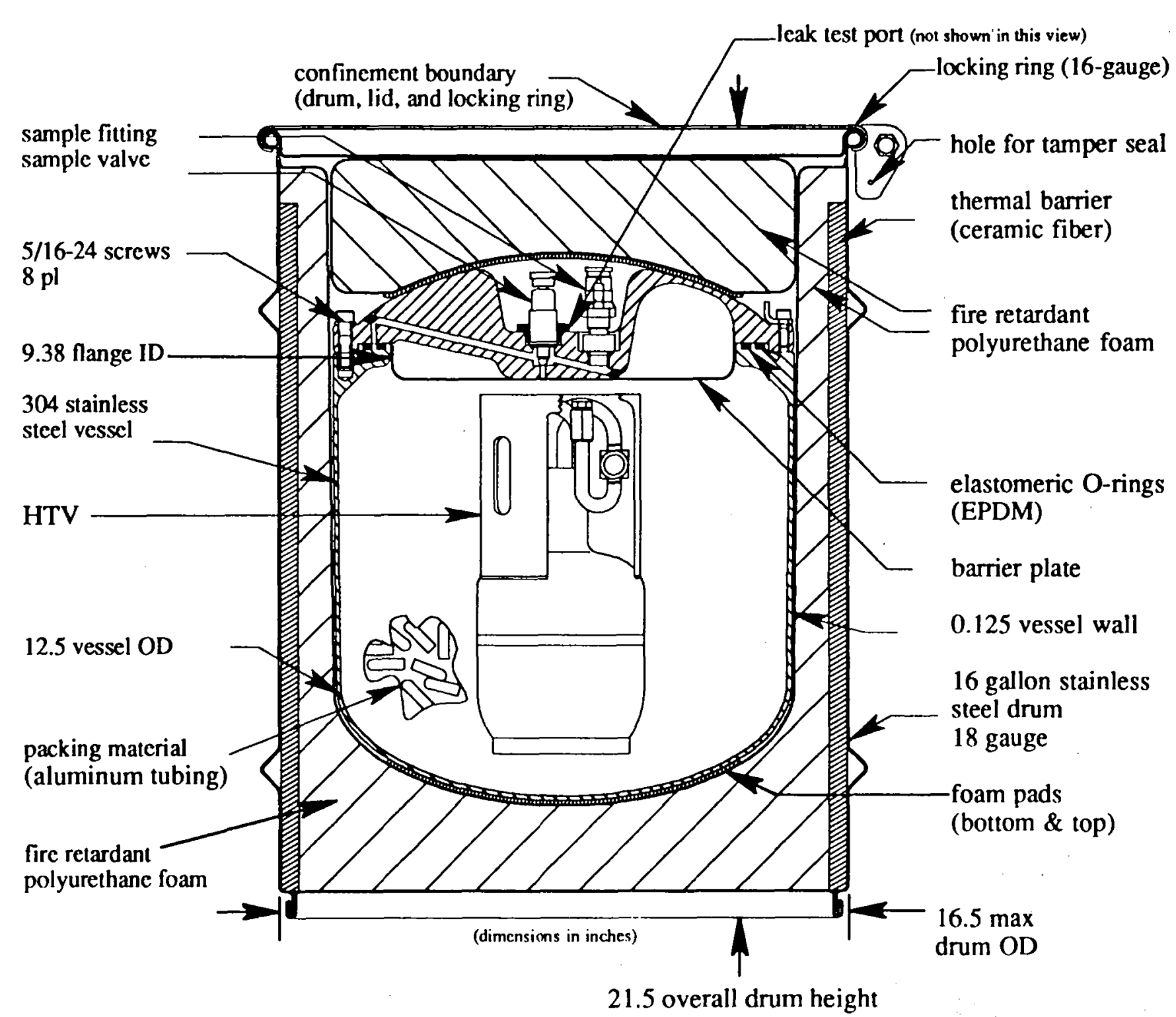




\section{Test Results}

The test sequence check sheet controlled the test activities and was completed appropriately (Appendix C). Steps 1,2, and 3 were done in the following order: 3 first, 1 second, and 2 third because the leak test had to be performed before the HTV was pressurized with helium. This change in the procedure was necessary and had no bearing on the test results. The test technician completed leak testing, pressurization, and assembly of the HTV (Figure 2 \& Figure 3(a)) and H1616-1 container. The valves on the HTV were torqued to $30 \pm 2 \mathrm{in.} \mathrm{lb}$ during assembly.

Department 2761-5 completed the vibration and shock testing as specified in the test plan (Figure 3(b)). Control accelerometer data is illustrated in Appendix D for the random vibration and shock tests.

A helium leak test performed on the H1616-1 containment vessel showed that no helium had leaked from the HTV during or following the tests. Actual leak test data is tabulated in Appendix $\mathrm{C}$ on page 30. Upon opening the H1616-1 containment vessel, the HTV was found in a horizontal orientation. The pressure of the HTV was also checked to determine if it actually contained the helium with which it was initially pressurized. The helium pressure was recorded as 9140 Torr (vs. 11010 initially) as the helium was expanded into an unpressurized volume containing plumbing and the pressure transducer. The difference in pressure is irrelevant as the purpose of this measurement was simply to verify the presence of helium. All components of the HTV were functional following the tests. As described in Appendix C, minor scratches on the vessel, some deformed packing material, and damaged plastic bag are expected in a test such as was carried out and have no detrimental effect on either the function of the H1616-1 or the HTV. 


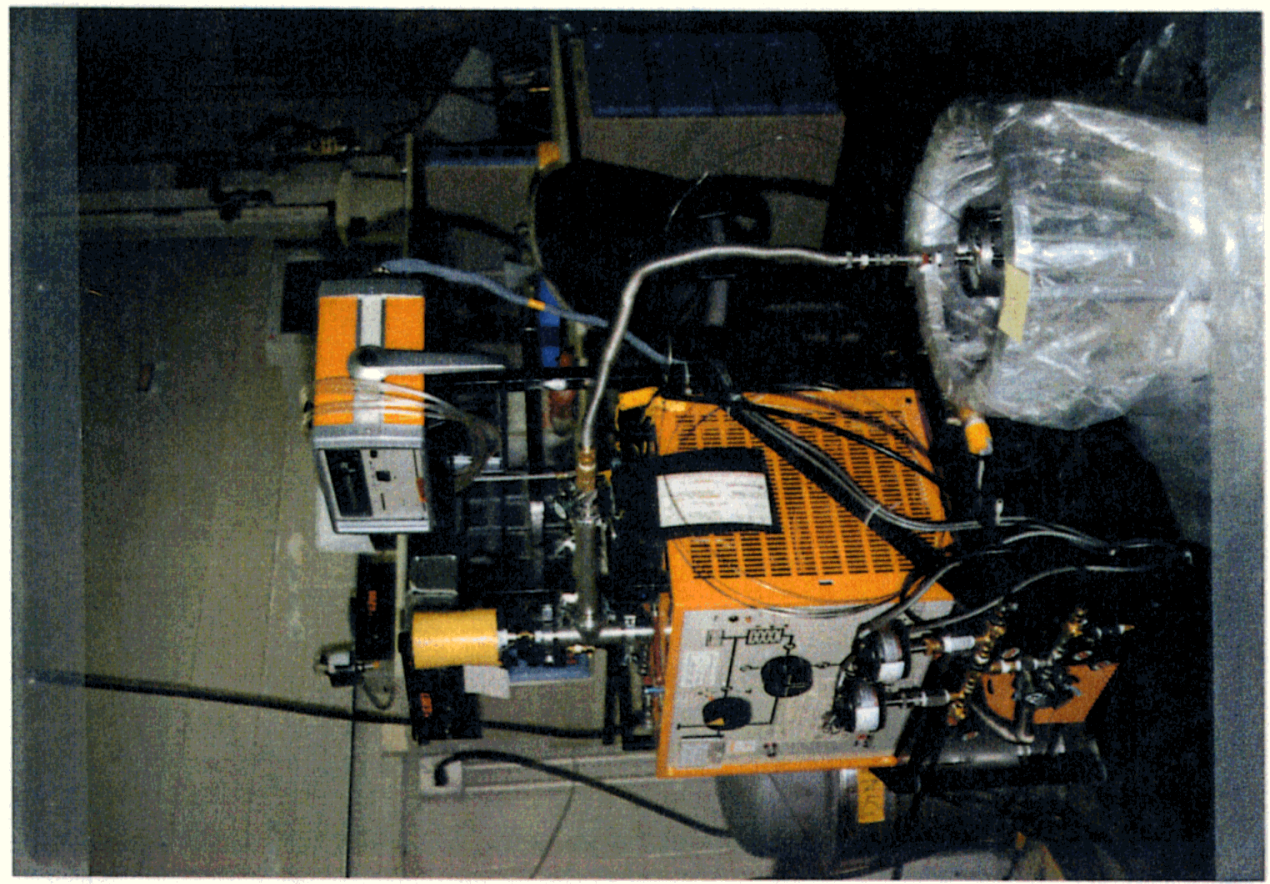

$\widehat{\varrho}$

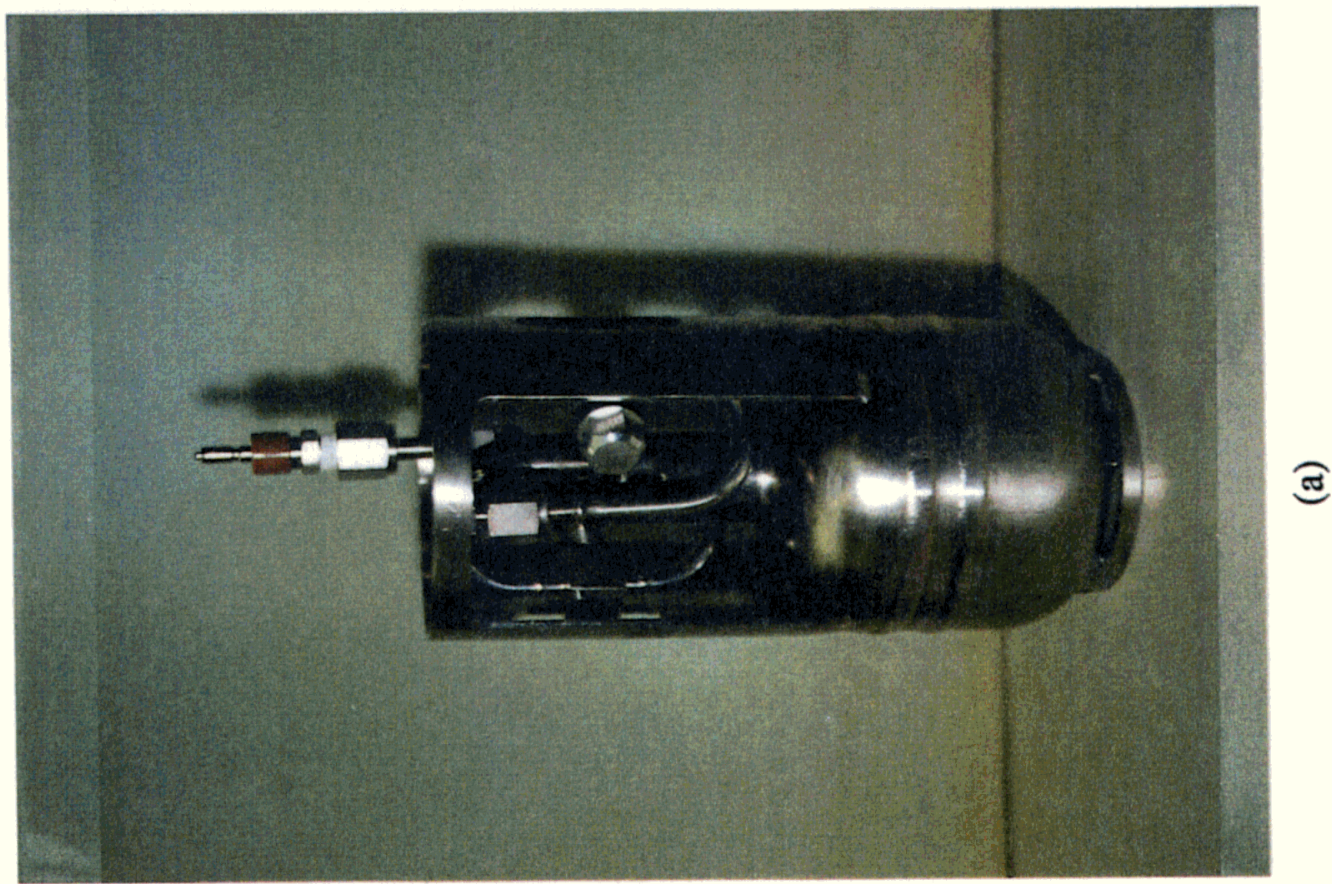

Figure 2. (a) HTV, (b) Initial Leak Testing of the HTV 

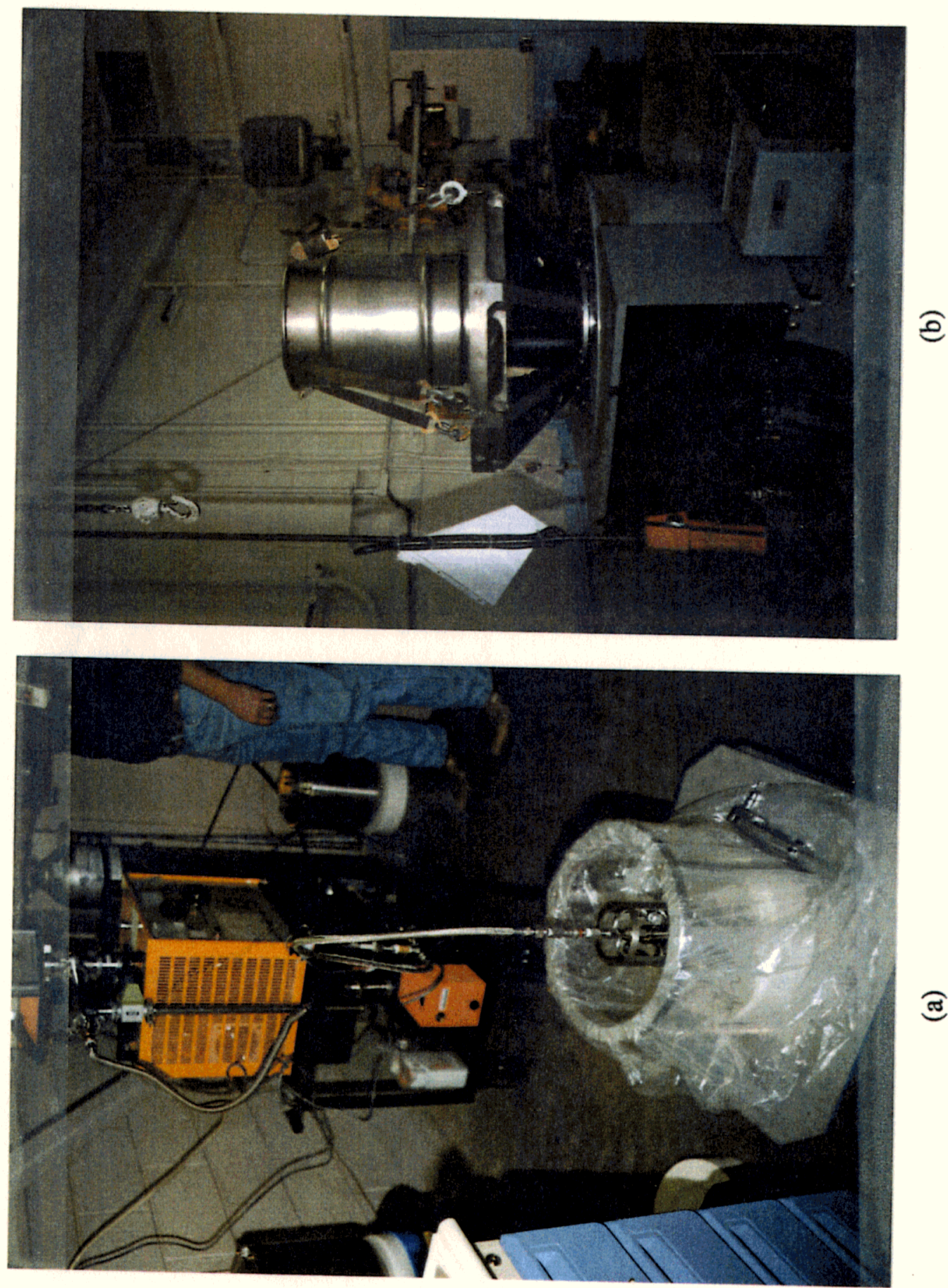

ঐ

Figure 3. (a) Pressurization of the HTV, (b) H1616-1 Mounted on the Vibration Table 


\section{References}

1 York, A.R., Transportation Environments of the AL-SX (H1616), SAND91-2204, Sandia National Laboratories, November 1991. 
Appendix A - Purchase Requisition No. D88600 Including Statement of Work 
WESTINGHOUSE SAVANNAH RIVER COMPANY 1000 BROOKHAVEN DR. AIKEN, SC. 29803

(FAX 203.644-1113. TEL. 803-644-1000)

U.S. DEPARTMENT OF ENERGY

CONTRACT ACO9-89SA-18035

TO

Sandia National Laboratory

P. O. Box 5800

Albuquerque, NM 87185

Attn: Ms. Ramona Nelson

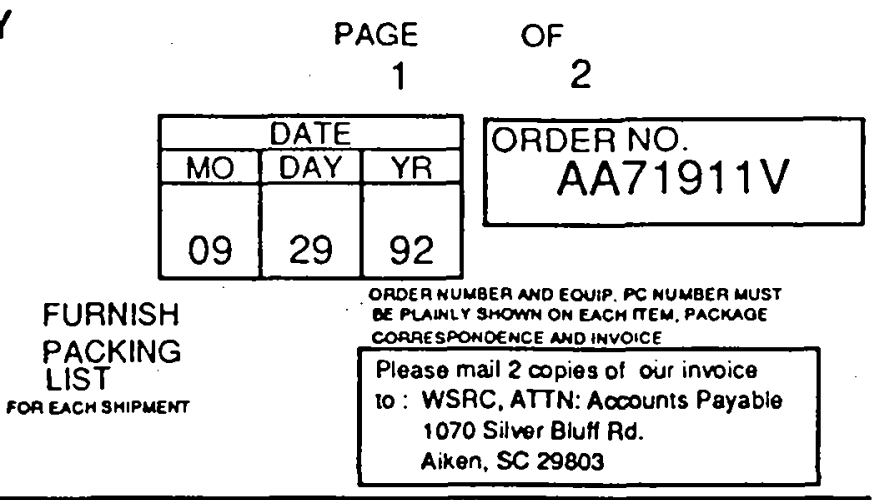

\begin{tabular}{ll}
\hline REOUIRED DELIVERY & PROMISED SHIPPING \\
See Below & See BelOW
\end{tabular}

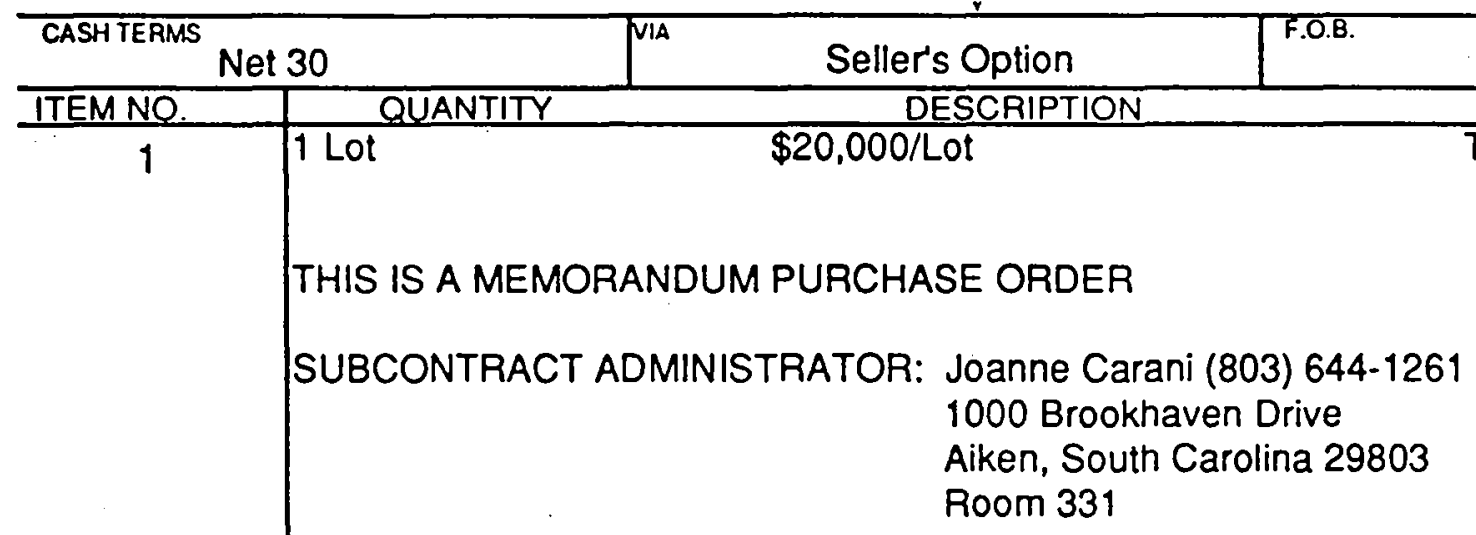

SUBCONTRACT TECHNICAL REPRESENTATIVE: George Lucky, (803) 725-4763

SCOPE OF WORK: Hydride Transport Vessel Vibration and Shock Testing as per attached workscope.

PERIOD OF PERFORMANCE: September 29, 1992 through December 31, 1992

PRINCIPAL PLACE OF PERFORMANCE: Sandia National Laboratory

COST/BILLING

Cost not to exceed $\$ 20,000.00$

Accounting Code: L4721H0OO-027

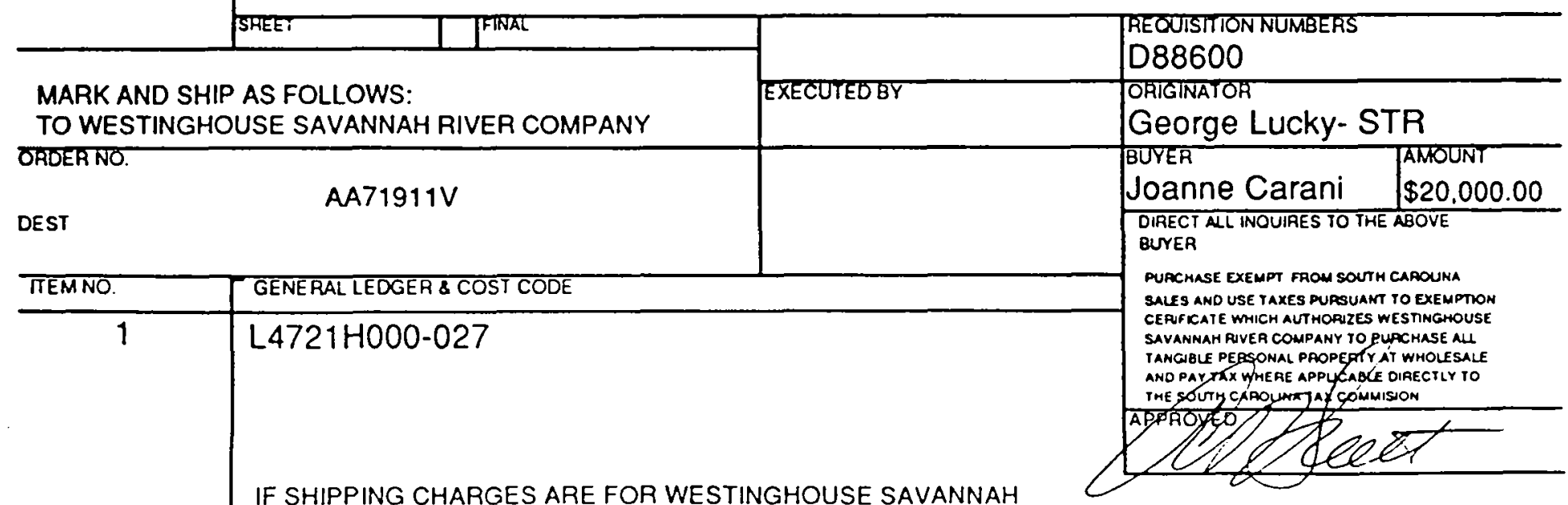

Destination

Total $\$ 20,000$ 
WESTINGHOUSE SAVANNAH RIVER COMPANY 1000 BROOKHAVEN DR. AIKEN. SC. 29803

(FAX 803.644.1113. TELE 803.644.1000)

U.S. DEPARTMENT OF ENERGY

CONTRACT ACO9.89SR-18035

TO

Sandia National Laboratory

P. O. Box 5800

Albuquerque, NM 87185

Attn: Ms. Ramona Nelson

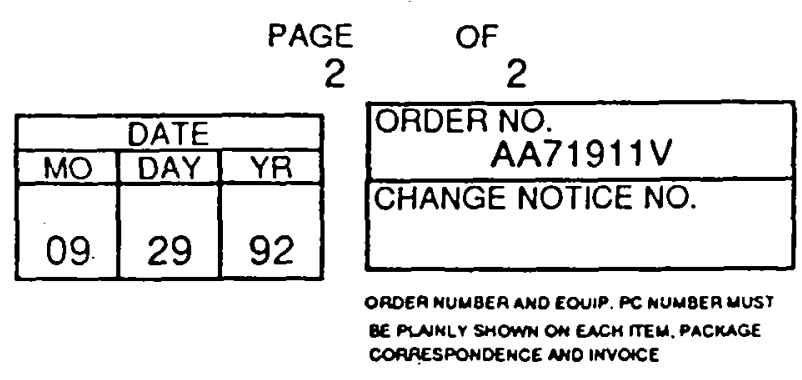



MAIL INVOICES TO:

Westinghouse Savannah River Company

1070 Silver Bluff Road

Aiken, South Carolina 29801

Accounts Payable Division

Please sign and return original of this MPO to Joanne Carani.

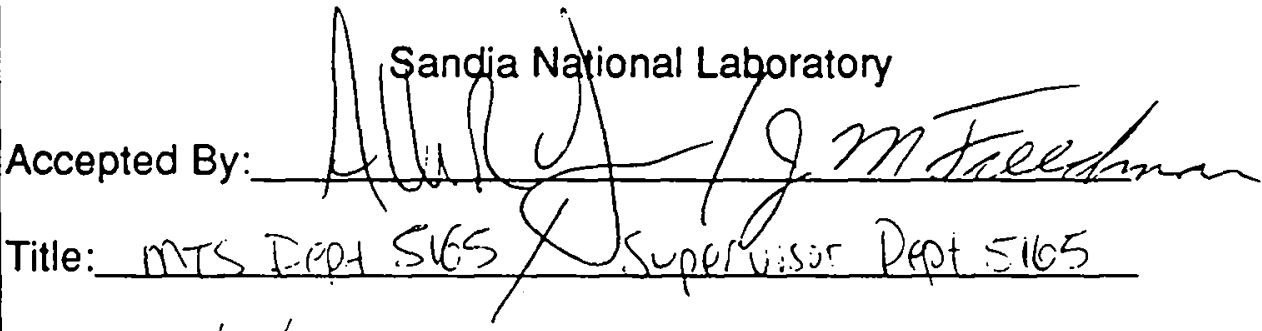

Date:

$10 / 12 / 62$

THIS DOCUMENT IS NOT A CONTRACT, IT IS A MEMORANDUM PURCHASE

ORDER ISSUED FOR SERVICES, EQUIPMENT AND OR MATERIALS UNDER U. S.

DEPARTMENT OF ENERGY (DOE) CONTRACT NUMBER DE-AC04-76DP00789

WHICH ARE NECESSARY AND REQUIRED IN CONNECTION WITH GOVERNMENT

CONTRACT DE-AC09-89SR18035. TERMS AND CONDITIONS REFERENCED ON

THIS ORDER, IF ANY, DO NOT APPLY. ACCOUNTING FOR THE COST OF THE

ABOVE SERVICE, EQUIPMENT, AND OR MATERIALS WILL BE MADE IN ACCORDANCE

WITH, AND AS REQUIRED BY, THE DOE CASH TRANSFER POLICY, DOE MANUAL

APPENDIX 1101, PART III, SECTION B, UNLESS OTHER DOE INSTRUCTIONS GOVERN.

ATTACHMENT: Workscope 


\section{JUSTIFICATION FOR PERFORMING WORK AT SANDIA NATIONAL LABORATORY-ALBUQUERQUE}

\section{Hydride Transport Vessel Vibration and Shock Testing}

The facilities necessary for this work are not available at Savannah River Site or in the local vicinity. Therefore, WSRC is requesting that the work be done by Sandia National LaboratoryAlbuquerque (SNLA) Organization 5165, hereafter referred to as SNLA. SNLA is qualified to perform this work based on the following:

1. SNLA originated the qualification requirements and criteria and has implemented them for previous testing.

2. SNLA has the necessary test and and verification capabilities. WSRC does not have the necessary test capabilities.

3. SNLA is the design agency for the H1616 packaging, within which the hydride transport vessel is to be tested and ulimately packaged.

\section{WORK SCOPE}

\section{Hydride Transport Vessel Vibration and Shock Testing}

\subsection{Introduction and Purpose}

1.1 This work scope covers the vibration and shock testing necessary to qualify the hydride transport vessel (HTV) for shipment in the Sandia-Albuquerque H1616 packaging.

1.2 The Westinghouse Savannah River Company organization L2720 (Packaging and Transportation Group), hereafter referred to as WSRC, is the requestor for this work.

1.3 The activities will be performed by Sandia National Laboratory-Albuquerque (SNLA) Organization 5165, hereafter referred to as SNLA.

\subsection{Objective}

2.1 SNLA is to satisfy the requirements of sections 3.0 and 4.0 below.

2.2 SNLA is to provide WSRC with the following:

2.2.1 A copy of the WSRC-approved test procedures used to perform this work.

2.2.2 A documented test report describing the test requirements and criteria, test parameters, test procedures, implementation, results, and assessment to the criteria.

\subsection{Qualification Test Requirements}

3.1 Test requirements are as follows: 
3.1.1 Sandia Specification SS393217, "Reservoir Qualification AL-SX (H1616)", paragraph 3.6, "Vibration" with appropriate scenario.

3.1.2 Sandia Specification SS393217, "Reservoir Qualification AL-SX (H1616)", paragraph 3.7, "Shock" with appropriate scenario.

3.2 Acceptance criteria are as follows:

3.2.1 Sandia Specification SS393217, "Reservoir Qualification AL-SX (H1616)", paragraph 3.10, "Acceptance criteria", further refined as follows:

3.2.1.1 The HTV shall remain leaktight to $<1 \times 10^{-7} \mathrm{std} \mathrm{cc} / \mathrm{sec}$ helium following exposure to the cited qualification requirements.

3.2.1.2 Leakage potentially occurring during testing will be monitor by determining if the HTV released helium into the H1616 containment vessel. Acceptance is no helium detected post-test in excess of an established pre-test background.

3.2.2 The HTV valves, fittings and tubing are to remain operable.

4.0 Qualification Test Description

4.1 WSRC will provide the HTV, which will be as follows:

4.1.1 The HTV, sketch 1 , is approximately 4.5 inches diameter by 10 inches tall, weighs approximately 10 pounds, and has 2 valves.

4.1.2 The HTV containment boundary is the vessel body and external tubing up to and including the valve seat seals.

4.1.3 The HTV will be prequalified for 200 psig service by proof testing to $250 \pm 5$ psig. The vessel will be provided unpressurized.

4.1.4 The prototype hydride transport vessel contains no depleted uranium or other hazardous material.

4.2 Test parameters are as follows:

4.2.1 Testing is to be done in either an H1616-1 or H1616-2 packaging.

4.2.1.1 SNLA is to provide the H1616 container.

4.2.1.2 The $\mathrm{H} 1616$ is to serve as a containment and test boundary for any helium leaked by the HTV during testing.

4.2.2 The HTV is to be packed in a Velostat ${ }^{\circledR}$ bag during shock and vibration testing.

4.2.3 Ambient temperature is to be used. Embrittement and thermal expansion stresses will be negligible over a $-40 \mathrm{C}$ to $71 \mathrm{C}$ temperature range for HTV's austenitic stainless steel construction. 
4.2.4 Testing is to be done with the HTV pressurized to its maximum normal operating pressure (MNOP) of 200 psig with helium.

4.2.5 Ambient external pressure is to be used. The MNOP assumes this rather than the actual $5 \pm 3$ psig expected in the H1616 during transport.

4.3 SNLA is to generate a test procedure which will include the following:

4.3.1 The following WSRC personnel are to approve the SNLA test procedure:

4.3.1.1 The WSRC engineer coordinating the testing.

4.3.1.2 The WSRC cognizant quality function (CQF) if the procedure is not approved by a SNLA CQF.

4.3.2 Preparation:

4.3.2.1 Pressurize and leak test the HTV.

4.3.2.2 If the HTV fails the leak test, SNLA is stop work and notify WSRC for disposition.

4.3.2.3 Package the HTV in the H1616.

4.3.2.4 Ensure that the $\mathrm{H} 1616$ assembly will retain any helium released from the HTV and determine the residual helium background.

4.3.3 Test Execution:

4.3.3.1 Perform the vibration and shock testing.

4.3.3.2 The H1616 and HTV containment boundaries must not be disturbed until post-test leak testing has been performed and, if failed, until WSRC has been notified and provided disposition.

4.3.4 Post-test evaluation:

4.3.4.1 If any of the following evaluations are failed, SNLA is to stop work and notify WSRC for disposition.

4.3.4.2 Test for helium in the H1616 to assess if the HTV leaked during vibration and shock testing.

4.3.4.3 Unload the H1616 and visually inspect the HTV and H1616 for damage or unusual conditions.

4.3.4.4 Leak test the HTV and verify that the pressurized helium has not been released.

4.3.4.5 Assess the operability of the HTV fittings, valves, and tubing. 

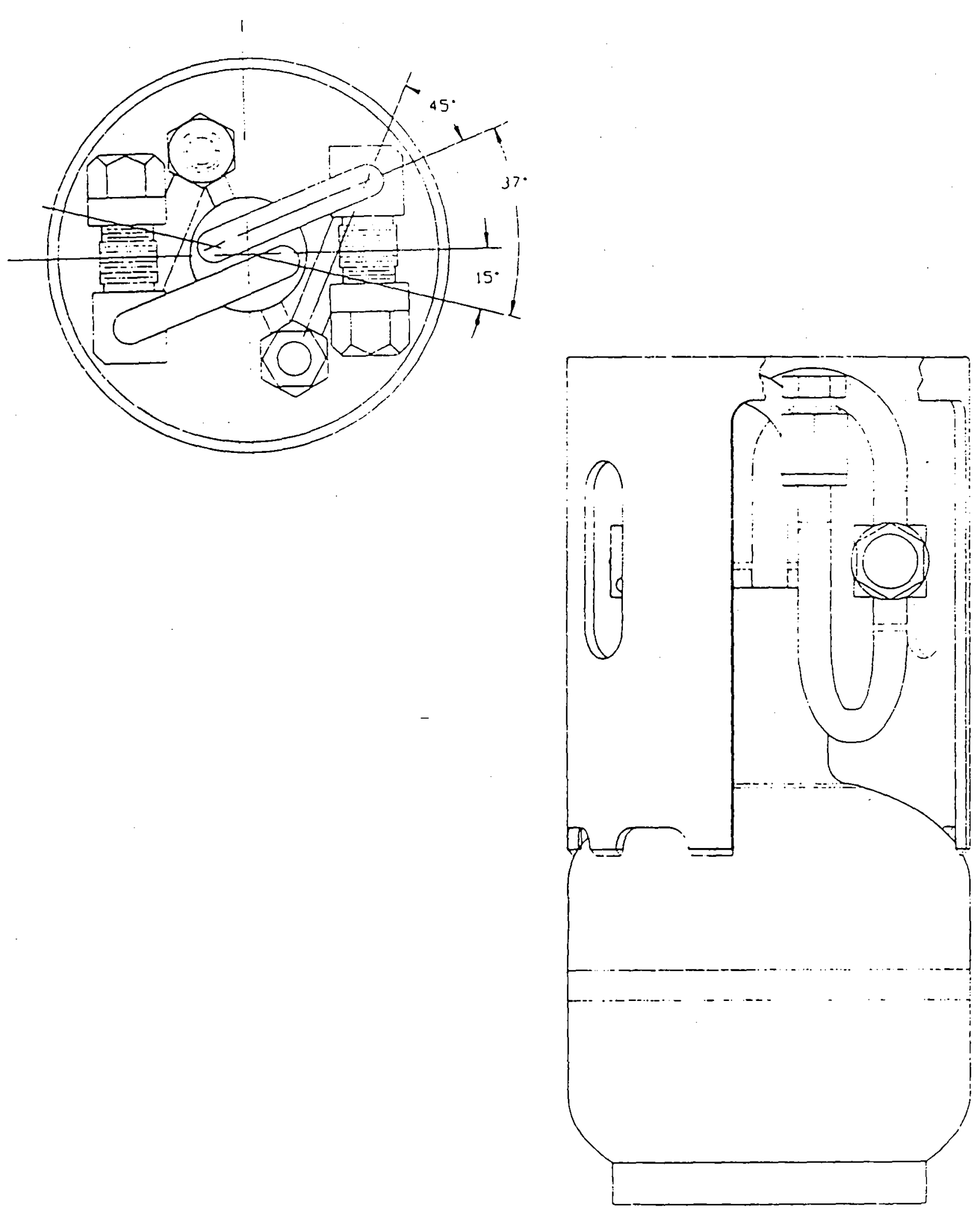

Sketch 1. IITV 
Appendix B - Plan for Testing the H1616 and the Savannah River Hydride Transport Vessel 
PREPARED BY:
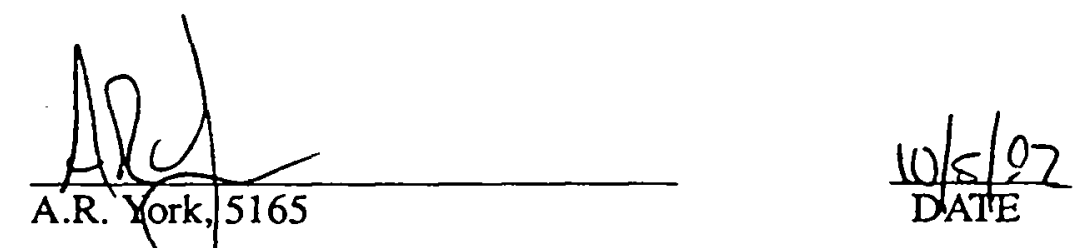

AL-SX SYSTEMS ENGINEER

APPROVED BY:

A

A.M.Freedman, 5165

MANAGER, DEPARTMENT 5165

$\frac{\text { lyallen/ }}{\text { R.S. Pacheco, } 5165}$

AL-SX Q.A. ENGDNEER

$\frac{\text { Ald fir mul see faxed sweet. }}{\text { M. VanAlstine }}$

WSRC TEST COORDINATOR

WSRC/SNL LLAISON

\section{$\frac{10 / 5 / 92}{\text { DATE }}$}

$\frac{10 / 5 / 92}{\text { DATE }}$

$\frac{10 / 5102}{\text { DATE }}$ 


\section{H1616/HYDRIDE TRANSPORT VESSEL TEST PLAN}

\section{REVISIONS and DISTRIBUTION}

Table 1. Issue Summary

\begin{tabular}{|c|c|l|}
\hline Issue & Date & \multicolumn{1}{c|}{ Comments } \\
\hline \hline $\mathrm{A}$ & $10 / 5 / 92$ & Original \\
\hline
\end{tabular}

Table 2. Distribution for Information Copies

\begin{tabular}{|l|c|c|}
\hline \multicolumn{1}{|c|}{ Name } & Organization & Copies \\
\hline \hline A.R. York & SNL 5165 & 1 \\
\hline J.M. Freedman & SNL 5165 & 1 \\
\hline R.E. Stinebaugh & SNL 5165 & 1 \\
\hline B.J. Joseph & SNL 5165 & 1 \\
\hline AL-SX File 8.5.5 & SNL 5165 & 1 \\
\hline T.L. Workman & SNL 2761-5 & 1 \\
\hline S. Klenke & SNL 2761-5 & 2 \\
\hline J. Pardo & WSRC L0130 & 1 \\
\hline M.N. VanAlstine & WSRC L2720 & 1 \\
\hline
\end{tabular}

Table 3. Controlled Copies

\begin{tabular}{|c|c|c|c|c|}
\hline Copy & Rev & Date & Org. & 5165 Project Task \\
\hline \hline A & A & B.J. Joseph & 5165 & Test Support Personnel \\
\hline
\end{tabular}

The signatures below verify receipt of Controlled Copies of this procedure.

Controlled Copy \#1 received by: date: 


\section{INTRODUCTION}

This test plan describes vibration and shock tests that will be performed on an $\mathrm{H} 1616$ shipping container. The H1616 packaging will contain a hydride transport vessel (HTV) pressurized with helium. The objective of the tests is to satisfy Requirements 3.6 and 3.7 in Sandia Specification SS393217, Reservoir Qualification AL-SX (H1616). Thus, the $\mathrm{H} 1616$ and hydride vessel contents will be subjected to vibration and shock normally incident to transport and helium leak tests will determine if the hydride vessel remains leaktight during and following the simulated transportation environments. The hydride vessel, manufactured from stainless steel and standard fittings and valves, is designed and procured by Westinghouse Savannah River Company (WSRC) and will not contain hazardous materials. The tests are scheduled to begin October 12, 1992.

\section{TEST UNIT}

The H1616 test unit will be an H1616-1 since this will be the main mode of transport for the HTV. The total weight of the H1616-1 with the HTV will be $\sim 131 \mathrm{lb}$.

The HTV (Figure 1) will be supplied by WSRC. The HTV consists of a body of 4.56-inch maximum diameter which is the pressure vessel. An impact protector that also serves as a lifting device is welded to the body and protects two Nupro valves and related tubing. The HTV weighs approximately $10 \mathrm{lb}$. The HTV will be pressurized to $200 \pm 5 \mathrm{psig}$ for the tests. The maximum allowable pressure of the $\mathrm{HTV}$ is $945 \mathrm{psig}$ at $600^{\circ} \mathrm{C}$, and the HTV used in this test will be proof tested to $300 \pm 5$ psig by WSRC prior to shipment to Sandia.

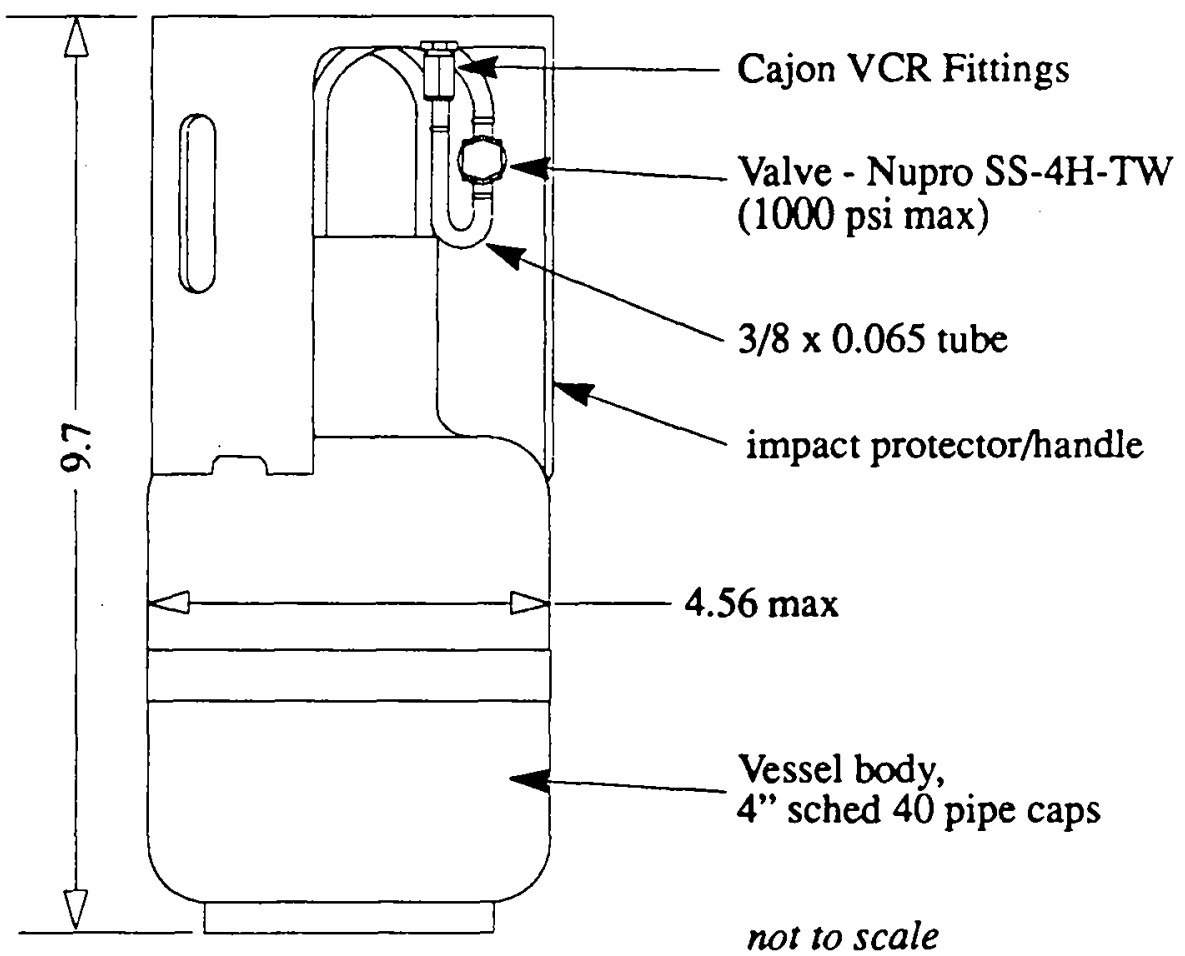

Figure 1. Hydride Transport Vessel 
The HTV will be filled with steel shot to simulate the contents. Since the HTV will be totally contained within the H1616 containment vessel, there will be no hazard if the HTV releases its pressure. The H1616-1 containment vessel is rated for 324 psig per the ASME Boiler and Pressure Vessel Code, and has a burst pressure of 1014 psig.

\section{TEST REQUIREMENTS}

The test requirements are generated from the transport scenario listed in Table 4 . The scenario was developed by WSRC and is specific to the HTV.

Table 4. Transport Scenario

\begin{tabular}{|l|l|l|}
\hline \multicolumn{1}{|c|}{ From } & \multicolumn{1}{c|}{ To } & \multicolumn{1}{c|}{ Transport Mode/Duration } \\
\hline \hline Facility 1 & Facility 2 & Road $/ 8 \mathrm{hr}$ \\
\hline Facility 2 & Airport 1 & Road / $1 \mathrm{hr}$ \\
\hline Airport 1 & Airport 2 & Air $/ 3 \mathrm{hr}$ \\
\hline Airport 2 & Airport 3 & Air $/ 3 \mathrm{hr}$ \\
\hline Airport 3 & Airport 4 & Air $/ 3 \mathrm{hr}$ \\
\hline Airport 4 & Airport 5 & Air $/ 8 \mathrm{hr}$ \\
\hline Airport 5 & Airport 6 & Air $/ 3 \mathrm{hr}$ \\
\hline Airport 4 & Interim Storage & Road $/ 45 \mathrm{~min}$ \\
\hline
\end{tabular}

The transport scenario listed in Table 4 is translated into specific transportation environments listed in Table 5. Since the HTV can migrate into any position in the H1616 containment vessel, only vertical vibration and shock spectra shall be used. The vertical spectra are, in general, more severe than those in the longitudinal or transverse directions.

Table 5. Transport Environments

\begin{tabular}{|l|l|l|}
\hline Transport Environment & \multicolumn{1}{|c|}{ Test Duration } & \multicolumn{1}{c|}{ Test Specification $^{\mathrm{a}}$} \\
\hline \hline Road & $9.75 \mathrm{hr}$ & Figure A.1, vertical \\
\hline Aircraft Cruise & $20.0 \mathrm{hr}$ & Figure A.6, vertical \\
\hline Aircraft Takeoff/Land & 5 sequences @ 5 min ea & Figure A.7, vertical \\
\hline Handling Shock & 16 shocks & Handling Shock, vertical \\
\hline
\end{tabular}

- See Appendix A of SAND91-2204 for these figures.

${ }^{b}$ This shock is defined in the Dept. 2761 computer for generating shocks. 


\section{VIBRATION and SHOCK TESTS}

\subsection{Test Parameters}

A total of 30 hours 10 minutes of vibration testing and 16 shocks shall be conducted by Department 2761, Environmental Test Department, at the vibration facility in Building 860 . The $\mathrm{H} 1616$ shall be secured to the vibration table in the vertical configuration. Testing shall be done at ambient temperature. The testing can be conducted in any order.

\subsection{Test Sequence}

Table 6. Test Sequence Steps

\begin{tabular}{|c|c|}
\hline Step & Description \\
\hline 1 & Pressurize HTV with $200 \pm 5$ psig helium. \\
\hline 2 & Secure HTV in a velostat bag with tape. \\
\hline 3 & $\begin{array}{l}\text { Perform A3.10.2 pressurized envelope leak test on HTV. Evacuate HTV and expose } \\
\text { exterior to a tent of helium while monitoring the MSLD. }\end{array}$ \\
\hline 4 & Load HTV in H1616 with longest dimension vertical. \\
\hline 5 & $\begin{array}{l}\text { Perform evacuated envelope helium leak test on the HTV while in the H1616. The } \\
\text { H1616 will act as a bell jar. }\end{array}$ \\
\hline 6 & $\begin{array}{l}\text { Complete assembly of the H1616 containment vessel and perform post load } \\
\text { innerseal pressure rise leak test. Assemble H1616 overpack. }\end{array}$ \\
\hline 7 & Transport H1616 to test facility in Building 860 . \\
\hline 8 & Conduct vibration and shock test. \\
\hline 9 & Transpor H1616 to building 809 . \\
\hline 10 & $\begin{array}{l}\text { Perform innerseal pressure rise leak test to verify integrity of the } \mathrm{H} 1616 \text { contain- } \\
\text { ment vessel following the tests. }\end{array}$ \\
\hline 11 & $\begin{array}{l}\text { Hook MSLD up to H1616 and monitor for helium. This step checks the leaktight- } \\
\text { ness of the HTV during and following the tests. }{ }^{\mathrm{a}}\end{array}$ \\
\hline 12 & Disassemble H1616, remove and inspect HTV for damage or unusual conditions. ${ }^{\text {a }}$ \\
\hline 13 & Verify that there is pressure in the HTV. ${ }^{\mathrm{a}}$ \\
\hline 14 & Vent HTV and inspect for damage. ${ }^{a}$ \\
\hline 15 & Verify function of valves and fittings on the HTV $\mathrm{V}^{\mathrm{a}}$ \\
\hline
\end{tabular}

${ }^{a}$ Hold point, if HTV fails evaluation notify WSRC. 


\subsection{Data Requirements and Documentation}

Accelerometers used to gather data shall have a valid calibration certificate.

Department 2731 shall provide the following:

- one PSD plot for each vibration run with a unique input,

- one shock response spectrum plot for the shock tests.

Calibrated transducers shall be used for data acquisition.

Department 5165 shall photograph the test setup during the tests and the HTV following the tests. A test report including all test documentation will be prepared and distributed to WSRC.

\section{HTV LEAK TEST EVALUATIONS}

The attached data sheet shall be completed by Department 5165 personnel. The MSLD used for leak testing and associated equipment shall have valid calibration certificates. Existing Department 5165 approved leak test procedures will be used.

\subsection{Pretest Helium Leak Test}

As listed in Table 6, two leak tests will be conducted on the HTV prior to the tests. The first shall be a pressurized envelope test where the MSLD is connected to the HTV, and the HTV is evacuated. When the pressure drops to the operating level of the MSLD, the exterior of the HTV will be surrounded by a tent of helium. The MSLD will be put in the test mode, and the appropriate data recorded.

The second leak test will be a bell jar type leak test on the HTV, and will be conducted after loading the HTV into the H1616 containment vessel. The containment vessel will be evacuated which will subject the exterior of the HTV to a vacuum. A leak in the HTV will be detected by the MSLD via the valve and quick connect on the H1616 containment vessel. s helium.

Acceptance of all helium leak tests requires a leak rate less than or equal to $1 \times 10^{-7} \mathrm{std} \mathrm{cc} /$

\subsection{Posttest Helium Leak Test}

The bell jar type leak test will be repeated following the vibration and shock tests to determine if the HTV leaked during or following the tests. 


\section{H1616/HTV TEST DATA SHEET}

Date:

Completed by:

H1616 s/n:

HTV s/n:

Table 7. Test Sequence Check Sheet

\begin{tabular}{|c|c|c|}
\hline Step & Description & $\begin{array}{l}\text { Enter Data or initial } \\
\text { complete }\end{array}$ \\
\hline 1 & Pressurize HTV with $200 \pm 5$ psig helium. & pressure: \\
\hline 2 & Secure HTV in a velostat bag with tape. & \\
\hline 3 & $\begin{array}{l}\text { Perform A3.10.2 pressurized envelope leak test on HTV. } \\
\text { Evacuate HTV and expose exterior to a tent of helium } \\
\text { while monitoring the MSLD. }\end{array}$ & $\begin{array}{l}\text { MSLD calibrated: } \\
\text { HTV leak rate: }\end{array}$ \\
\hline 4 & Load HTV in H1616 with longest dimension vertical. & \\
\hline 5 & $\begin{array}{l}\text { Perform evacuated envelope helium leak test on the HTV } \\
\text { while in the H1616. The H1616 will act as a bell jar.a }\end{array}$ & $\begin{array}{l}\text { MSLD calibrated: } \\
\text { Total leak rate: }\end{array}$ \\
\hline 6 & $\begin{array}{l}\text { Complete assembly of the } \mathrm{H} 1616 \text { containment vessel and } \\
\text { perform post load innerseal pressure rise leak test. Assem- } \\
\text { ble H1616 overpack. }\end{array}$ & $\begin{array}{l}\text { pressure rise } \\
\text { leak rate: }\end{array}$ \\
\hline 7 & Transport H1616 to test facility in Building 860 . & \\
\hline 8 & Conduct vibration and shock test. & \\
\hline 9 & Transport H1616 to building 809 . & \\
\hline 10 & $\begin{array}{l}\text { Perform innerseal pressure rise leak test to verify integrity } \\
\text { of the H1616 containment vessel following the tests. }\end{array}$ & $\begin{array}{l}\text { pressure rise } \\
\text { leak rate: }\end{array}$ \\
\hline 11 & $\begin{array}{l}\text { Hook MSLD up to H1616 and monitor for helium. This } \\
\text { step checks the leaktightness of the HTV during and fol- } \\
\text { lowing the tests. }\end{array}$ & $\begin{array}{l}\text { MSLD calibrated: } \\
\text { HTV leak rate: }\end{array}$ \\
\hline 12 & $\begin{array}{l}\text { Disassemble } \mathrm{H} 1616 \text { and remove and inspect HTV for } \\
\text { damage or unusual conditions. }\end{array}$ & \\
\hline 13 & Verify that there is pressure in the $\mathrm{HTV}^{\mathrm{a}}$ & pressure: \\
\hline 14 & Vent HTV and inspect for damage. ${ }^{\mathrm{a}}$ & \\
\hline 15 & Verify function of valves and fittings on the HTV ${ }^{a}$ & \\
\hline
\end{tabular}

a Hold point, if HTV fails evaluation notify WSRC. 


\section{Appendix C - Test Data Sheet and Test Notes}




\section{Savannah River Hydride Transport Vessel Disassembly Notes}

\section{Overpack and Insert Cover}

The exterior surface of the overpack appeared as they did prior to the vibration test. The locking ring bolt and nut were still tight and the lead seal was still in place.

The interior surfaces of the overpack appeared as they did prior to the vibration test.

The top surface of the insert cover appeared to have small scratches. The scratches appeared circular (as though the insert cover had rotated).

\section{Containment Vessel}

The exterior surface of the containment vessel appeared as it did prior to the vibration test.

The lid bolts remained torqued and the interior surface appeared as it did prior to the vibration test.

The interior sides of the containment vessel body had some areas that appeared polished and other marks that appeared to be caused by rotation. The radial marks appeared $\sim 2$

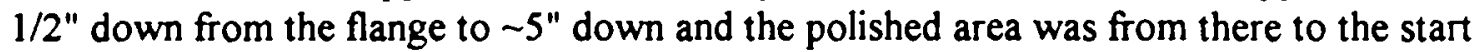
of the bottom radius. There were a few marks on the very bottom of the vessel and some residual aluminum and plastic particles.

\section{Packing Shells}

The packing shells were highly polished and a few showed signs of possibly being worn and deformed.

\section{Hydride Transport Vessel}

Packing shells were removed to locate the vessel. The vessel had migrated to the bottom of the H1616-1 containment vessel body. The vessel was positioned horizontally in a position where the top and bottom edges were probably resting on the bottom radius of the H1616-1 cavity.

\section{Velostat Bag}

The velostat bag was still enclosing the vessel, however, portions of the top and bottom edges of the vessel had worn through and there were areas around both valves where the plastic was worn through. The packing shells had indented and distorted the remainder of the bag surface. 


\section{H1616/HTV TEST DATA SHEET}

Date: Oct 92

H1616 s/n: Lid: SBT-X0203 Body: SBT-X0201
Completed by:

HTV s/n: Proto $\# \dot{3}$

Table 7. Test Sequence Check Sheet

\begin{tabular}{|c|c|c|}
\hline Step & Description & $\begin{array}{l}\text { Enter Data or initial } \\
\text { complete }\end{array}$ \\
\hline 12 & Pressurize HTV with $200 \pm 5$ psig helium. & pressure: $11,010 \operatorname{Tok}^{10}$ \\
\hline 23 & Secure HTV in a velostat bag with tape. & $1019: 92$ \\
\hline 3 & $\begin{array}{l}\text { Perform A3.10.2 pressurized envelope leak test on HTV. } \\
\text { Evacuate HTV and expose exterior to a tent of helium } \\
\text { while monitoring the MSLD. }\end{array}$ & $\begin{array}{l}\text { MSLD calibrated: } 10 i a: 92 \\
\text { HTV leak rate: }<3.2 \times 1 .\end{array}$ \\
\hline 4 & Load HTV in H1616 with longest dimension vertical. & $10 / 9 / 9,2 \quad \therefore$ \\
\hline 5 & $\begin{array}{l}\text { Perform evacuated envelope helium leak test on the HTV } \\
\text { while in the H1616. The H1616 will act as a bell jar. }\end{array}$ & $\begin{array}{l}\text { MSLD calibrated: } 10 \\
\text { Total leak rate: } \\
<3.2 \cdots-4\end{array}$ \\
\hline 6 & $\begin{array}{l}\text { Complete assembly of the } \mathrm{H} 1616 \text { containment vessel and } \\
\text { perform post load innerseal pressure rise leak test. Assem- } \\
\text { ble H1616 overpack. }\end{array}$ & 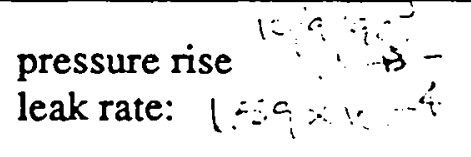 \\
\hline 7 & Transport H1616 to test facility in Building 860 . & (r) acis r \\
\hline 8 & Conduct vibration and shock test. & $10: 12-1015, k$ \\
\hline 9 & Transport H1616 to building 809 . & $10:$ 几 \\
\hline 10 & $\begin{array}{l}\text { Perform innerseal pressure rise leak test to verify integrity } \\
\text { of the H1616 containment vessel following the tests. }\end{array}$ & $\begin{array}{l}\text { pressure rise } \\
\text { leak rate: }\end{array}$ \\
\hline 11 & $\begin{array}{l}\text { Hook MSLD up to H } 1616 \text { and monitor for helium. This } \\
\text { step checks the leaktightness of the HTV during and fol- } \\
\text { lowing the tests. }\end{array}$ & 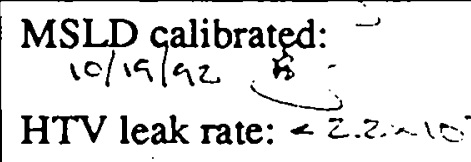 \\
\hline 12 & $\begin{array}{l}\text { Disassemble } \mathrm{H} 1616 \text { and remove and inspect HTV for } \\
\text { damage or unusual conditions. }\end{array}$ & 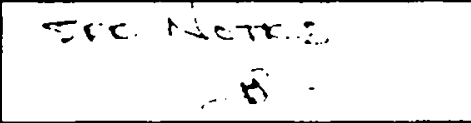 \\
\hline 13 & Verify that there is pressure in the HTV. ${ }^{a}$ & 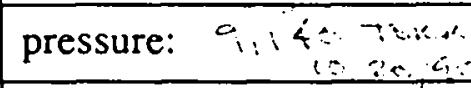 \\
\hline 14 & Vent HTV and inspect for damage. ${ }^{a}$ & $10 / 20192 E-$ \\
\hline 15 & Verify function of valves and fittings on the HTV ${ }^{a}$ & $\omega_{i}^{i} z \cdots a_{2}^{\prime} F_{-}$ \\
\hline
\end{tabular}

" Hold point, if HTV fails cvaluation notify WSRC. 
Appendix D - Control Accelerometer Data 


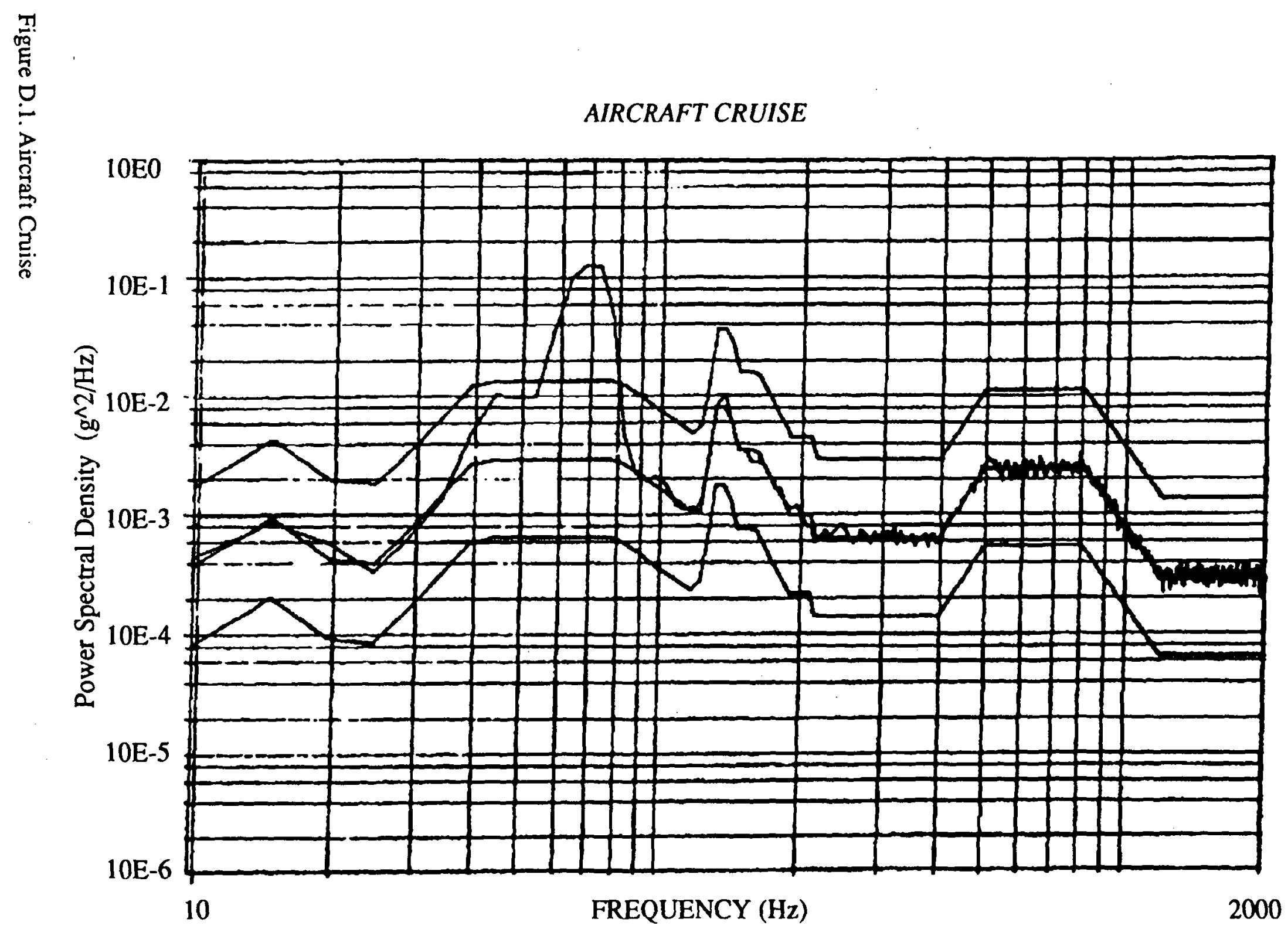




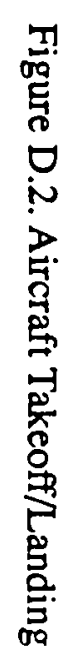

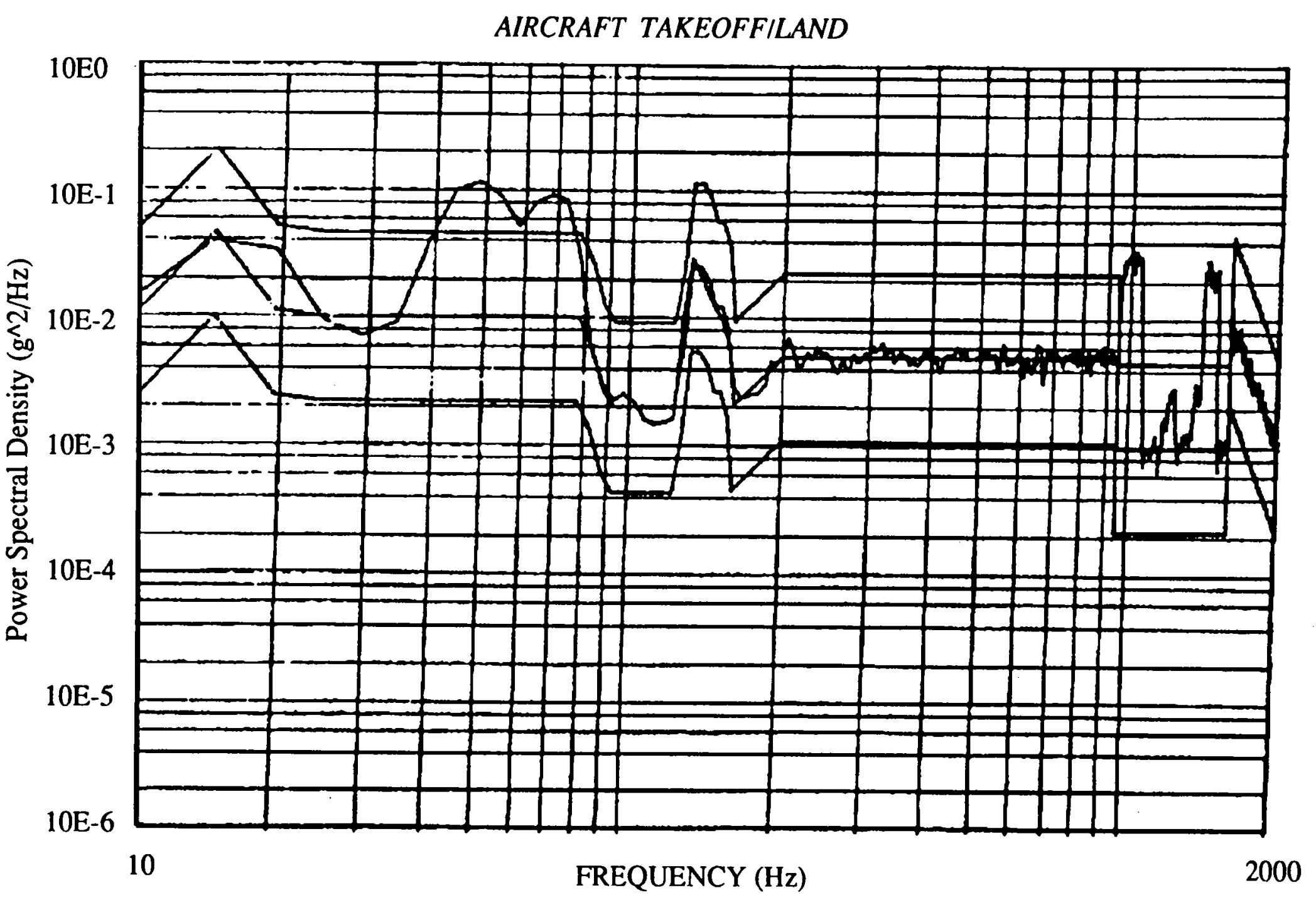


ROAD

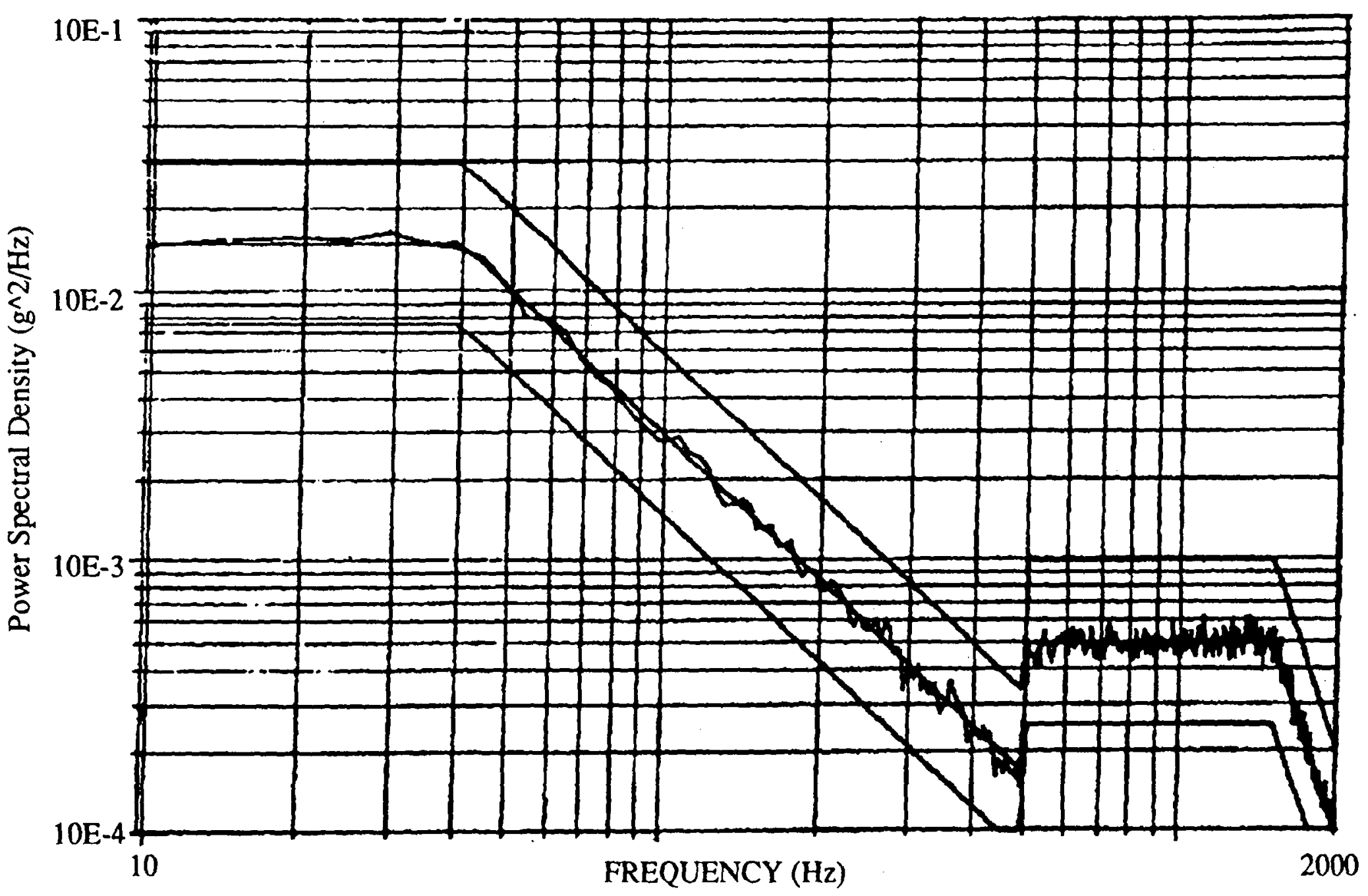




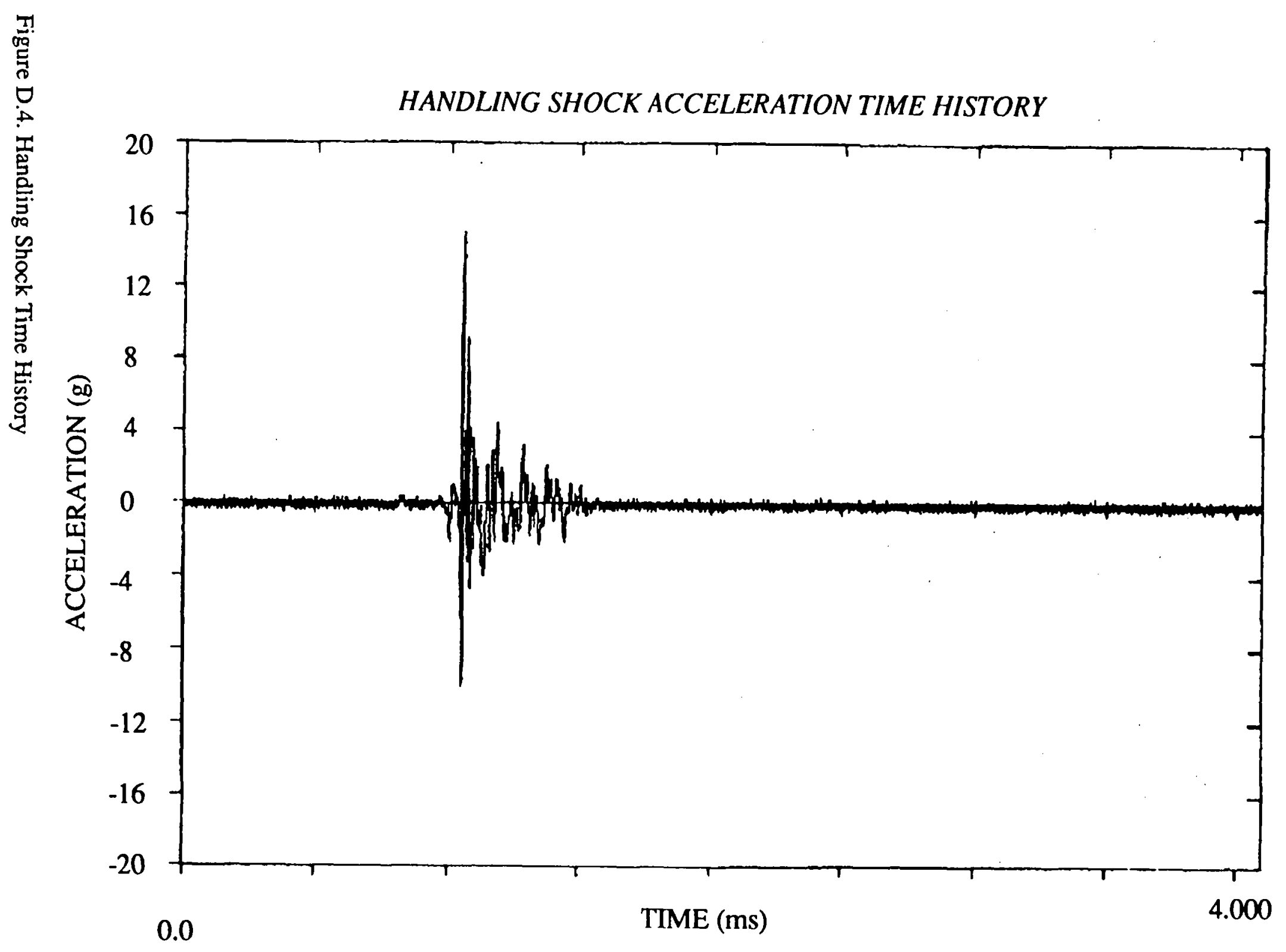




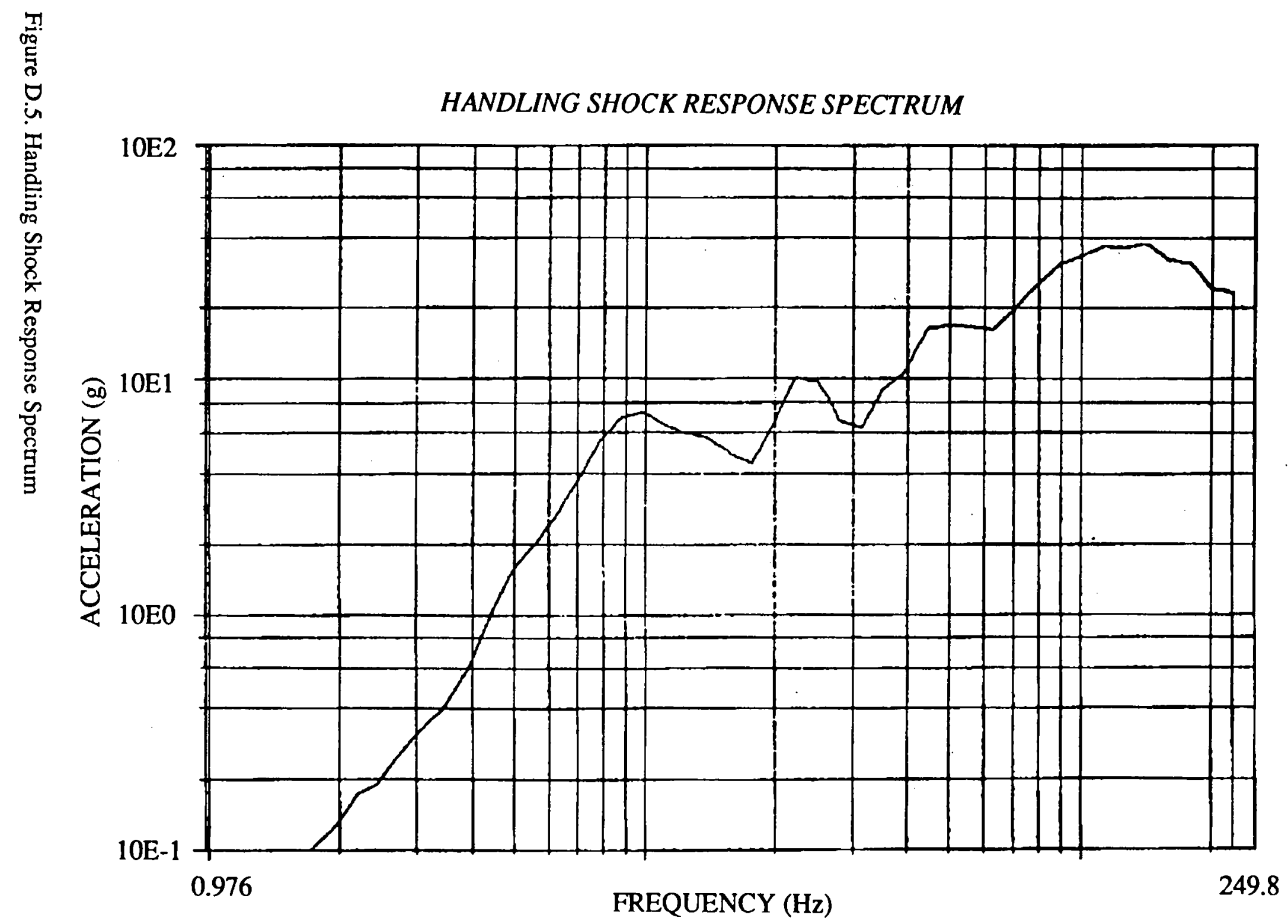




\section{Distribution}

3 M.N. VanAlstine

Westinghouse Savannah River Company

Bldg. 305-2A

Aiken, SC 29808

\begin{tabular}{|c|c|c|}
\hline 4 & 5165 & A.R. York \\
\hline 1 & 5165 & B.J. Joseph \\
\hline 1 & 5165 & R.E. Stinebaugh \\
\hline 1 & 5165 & AL-SX File 20.2 \\
\hline 1 & $2761-5$ & S. Klenke \\
\hline 5 & 7141 & Technical Library \\
\hline 10 & 7613-2 & Document processing for DOE/OSTI \\
\hline 1 & 7151 & Technical Publications \\
\hline 1 & $8523-2$ & Central Technical Files \\
\hline 1 & DOE/AI & P.G. Seamster \\
\hline 5 & DOE/AI & S.B. Fellows \\
\hline
\end{tabular}

